Jpn. J. Hosp. Pharm.

$\left[\begin{array}{ll}\text { 19(3) } & 209-215 \\ \text { (1993) }\end{array}\right]$

\title{
ニフェジピン持効性細粒の溶出特性と光安定性
}

\author{
坂爪重明, 山下恒弘, 小野畺理子, 佐藤 博, 丹野慶紀*
}

新潟大学医学部附属病院薬剤部

\section{Dissolution Properties and Photostabilities of a Sustained Release Nifedipine Fine Granules}

\author{
Shigeaki Sakazume, Tunehiro Yamashita, Mariko ONo, \\ Hiroshi SATOH, KEIKI TANNO* \\ Division of Pharmacy, Niigata University Medical Hospital $\dagger$
}

$\left(\begin{array}{l}\text { Received November } 24,1992 \\ \text { Accepted January } 12,1993\end{array}\right)$

\begin{abstract}
A sustained release nifedipine fine granules, Sepamit $R$ Granules ${ }^{\circledR}$ (SP-RG), is a product prepared by using the technique of solid dispersion. Dissolution behavior of nifedipine from SP-RG was tested based on the results of incompatibility. The photostability of SP-RG was also tested. Dissolution rate of nifedipine from SP-RG was $12.5 \%$ in JP XII 1st disintegration test fluid ( $\mathrm{pH} \mathrm{1.2)}$ and $100.9 \%$ in JP XII 2nd disintegration test fluid (pH 6.8). Dissolution of nifedipine in JP XII 2nd fluid was delayed by moisture absorption during storage (relative humidity of $75 \%$ at $20^{\circ}$ for 30 days). Dissolution of nifedipine from SP-RG in JP XII 1st fluid was increased by mixing of SP-RG with sodium bicarbonate or heavy magnesium oxide during storage (relative humidity of $75 \%$ at $20^{\circ}$ for 30 days).

Nifedipine in SP-RG packaged with polyethylene cellophan laminate paper completely decomposed after 72 hours, under exposure to light $(500 \mathrm{lux})$, while it was stable even after 30 days with aluminium polyethylene laminate paper.
\end{abstract}

Keywords_— nifedipine fine granules; sustained release granules; dissolution rate; incompatibility; photostability

従来, ニフェジピン持効性製剤として, 錠剤や カプセル剂などが市販されている．用量の微調節 あるいは錠剤拉よびカプセル剂を服用できない経 管投与患者などにおいては散剂の製剂が有用であ る.しかし，腸溶性コーティングを施した細粒 は，製剤粒子の表面積が著しく大きくなり，また 無定形の薬剂に剂皮を完全に施すことが困難であ るため製造が難しかった。

†新潟市旭町通1-754；1-754, Asahimachidori, Niigata-shi, 951 Japan
近年, 固体分散体手法により難溶性薬物の溶解 度および溶解速度を向上させて, 薬物の腸管から の吸収率を上げる研究がなされている1 3). その中 で，腸溶性固体分散体の技術を用い製剂化したセ パミット R 細粒 (SP-RG) が最近市販された.

前報4では，臨床上本製剂と配合が予想される 医薬品のらち，30品目を対象として配合後の経時 的外観変化, 重量増加率を報告した. 今回は SP$\mathrm{RG}$ ならびに SP-RG と配合して経時的外観変化 (流動性低下, 固化, 湿潤, 色調変化など $)^{4)}$ で 
変化が認められたもの 2 種類と, 变化が認められ ないもの 2 種類, および制酸剂 2 種類について, ニフェジピンの溶出挙動を in vitroで調べた.さ らにSP-RG を粉砕して微末化した時, 固体分散 体にどのような影響を与えるかを溶出挙動より検 討した。 また，本製剤のニフェジピンの光に対す る安定性 ${ }^{5,6)}$ についても検討した.

\section{実 験 の 部}

\section{1. 溶出試験}

1) 試験薬

被験薬としてニフェジピンを $2 \%$ 含有する SPRG（鐘紡株式会社，Lot. 11-3）を用いた. SP$\mathrm{RG}$ を含む配合薬は，前報で経時的外観变化の認 められたラック B 微粒（日研化学株式会社）とフ スタギン（三共株式会社）を用いた。 また変化が 認められないものとして，乳酸カルシウム（丸石 製薬株式会社）とミヤ BM（ミヤリサン株式会 社)，ならびに制酸剤として炭酸水素ナトリウム

（吉田株式会社）と重質酸化マグネシウム（丸石 製薬株式会社）をそれぞれ用いだ．

2) 試料の調製

SP-RG の $0.75 \mathrm{~g}$ を精密に量り, Table 1 に 示した配合薬のそれぞれの量を精密に量って乳鉢 で混和し，分包機でポリエチレンセロファンラミ ネート紙により包装した．非分包品は分包品と同 様に量り，それぞれ秤量瓶にとり，層の厚さが約 $5 \mathrm{~mm}$ となるように設定した。なお配合量は添付 文書からそれぞれの 1 日服用量の 1 回分に相当す る量を基準に決定した.

また，粉砕して微末化した試料は，SP-RGを

Table 1. The Amount of Compatible Agents to SP-RG (0.75g)

\begin{tabular}{llc}
\hline \multicolumn{1}{c}{ compatible agent } & lot. no. $\begin{array}{l}\text { the amount } \\
\text { of compatible } \\
\text { agent (g) }\end{array}$ \\
\hline LAC B & 680111 & 1.50 \\
hustagine & L 186 Y & 0.75 \\
calcium lactate & 1222 & 1.17 \\
MIYA BM & $19 \mathrm{~S} \mathrm{031}$ & 0.75 \\
sodium bicarbonate & 291011 & 1.33 \\
heavy magnesium oxide & 1201 & 0.25 \\
\hline
\end{tabular}

小西医療器株式会社製調剂用粉砕器を用いて粉砕 し微末化した後, 200 ッシュのふるい $(75 \mu)$ で 全通させて用いた。

3）保存条件

SP-RG 製剤並びに SP-RG を含む配合薬につ いて，それぞれの分包品と非分包品を日本薬剤師 会調剂技術委員会の報告7) に従い，中間条件 $20^{\circ}$ C, RH75\%並びに最悪条件 $30^{\circ} \mathrm{C}, \mathrm{RH} 92 \%$ に保 ち，遮光下で30日間保存した。な和照として開 封直後の SP-RG を用いた. 恒温恒湿器は, ナガ ノ科学製の LI-30-02 を完全に遮光して用いた.

\section{4）溶出試験方法}

溶出試験方法は, 第12改正日本薬局方溶出試験 第 2 法により, 富山産業の溶出試験器(NTR-5S3 型）を用いて行った。回転数は $150 \mathrm{rpm}$ とした。 試験液は日局の崩壊試験法第 1 液（日局第 1 液） および第 2 液（日局第 2 液）を用いそれぞれ 900 $\mathrm{ml}$ とした. 日局第 1 液については, SP-RG なら びに SP-RG を含む配合薬について, ニフェジピ ンとして約 $10 \mathrm{mg}$ に対応する量, 日局第 2 液は二 フェジピンとして約 $5 \mathrm{mg}$ に対応する量を溶出試 験の試料とした．次に経時的に試験液から $10 \mathrm{ml}$ を採取して測定試料とした。 また試験液は減少分 をそのつど補充した。

\section{5）定量法}

ニフェジピンの定量は秋本らの方法 ${ }^{8)}$ に準じて 行った. 溶出液を $0.45 \mu \mathrm{m}$ のミリポアフィルター でろ過し， ろ液 $1.0 \mathrm{ml}$ に内部標準物質として安 息香酸イソプロピル $(0.04 \mathrm{mg} / \mathrm{ml})$ を加えて混合 後, $10 \mu 1$ を高速液体クロマトグラフィー(HPLC) に注入した. ニフェジピン量は内部標準法でピー ク面積比を算出し, あらかじめ作成した検量線か らニフェジピン濃度を求めた。 また溶出試験およ び試料測定は暗室中赤色灯下で行い, 光の影響を 極力避けた。

6） HPLC 装置および測定条件

ポンプ : LC-3A(島津製作所), 検出器 : SPD$3 \mathrm{~A}$ (島津製作所), カラム: Unisil-pack (島津 製作所） $5 \mathrm{c} 18-150 \mathrm{~A}(4.6 \times 150 \mathrm{~mm})$, カラム温 度 : 室温, 移動相 : メタノール・水 $(64: 36)$, 流 速 $: 1.0 \mathrm{ml} / \mathrm{min}$, 検出波長 $: 254 \mathrm{~nm}$. 


\section{2. 光安定性試験}

1）試料の調製

SP-RG の $0.75 \mathrm{~g}$ ずつをポリエチレンセロファ ンラミネート紙と赤色グラシン紙で包装した。 たポリエチレンセロファン紙で包装したものをア ルミニウムポリェチレンラミネート紙で再包装し 対照品とした。

\section{2) 光照射条件}

室内白色螢光灯 (FS2014E. 20W; 日 立製 作 所）を用い, 平均照度 $500 \mathrm{lux}$, 平均湿度 $35 \%$ の 室温条件で行った。ポリエチレンセロファンラミ ネート紙ならびに赤色グラシン紙に包装した試料 は, 72時間光照射を行い, アルミニウムポリェチ レンラミネート紙で再包装した試料については, 720 時間光照射を行った. また試験期間中は振と ら機（KS-2, サクラ精機）を用いて試料にまん ベんなく光照射を行った.

\section{3）定量法}

試料から $0.5 \mathrm{~g}$ を精密に量り,メタノール約 80 $\mathrm{ml}$ を加光, 10分間超音波処理した後, メタノー ルを加えて正確に $100 \mathrm{ml}$ とした。 これを遠心分 離 $(3000 \mathrm{rpm} \times 10 \mathrm{~min})$ した後, 上澄液 $1.0 \mathrm{ml}$ に 内部標準物質として安息香酸イソプロピル（0.2 $\mathrm{mg} / \mathrm{ml}$ ) を加えて混合後, $10 \mu \mathrm{l}$ を HPLC に注 入し, 前記の HPLC 法により検量線からニフェ ジピン濃度を求めた. また試料測定は暗室中赤色 灯下で行い, 光の影響を極力避けた.

\section{結果}

\section{1. 無包装の SP-RG 製剤におけるニフェジピ} ンの溶出挙動

日局第 1 液による SP-RG の溶出試験 では,

Fig. 1 に示すように，いずれの保存条件下にお いても, 試験開始60分後におけるニフェジピンの 溶出率は, 溶出試験に用いた本製剤のニフェジピ ン含量に対して約10\%であった．日局第 2 液の溶 出試験では, 試験開始10分後における開封直後な らびに $20^{\circ} \mathrm{C}, \mathrm{RH} 75 \%$ で30日間保存後の SP-RG からのニフェジピンの溶出率は約 $100 \%$ であった. また $30^{\circ} \mathrm{C}, \mathrm{RH} 92 \%$ で30日間保存後の SP-RG か らの=フェジピンの溶出率は試験開始10分後に約

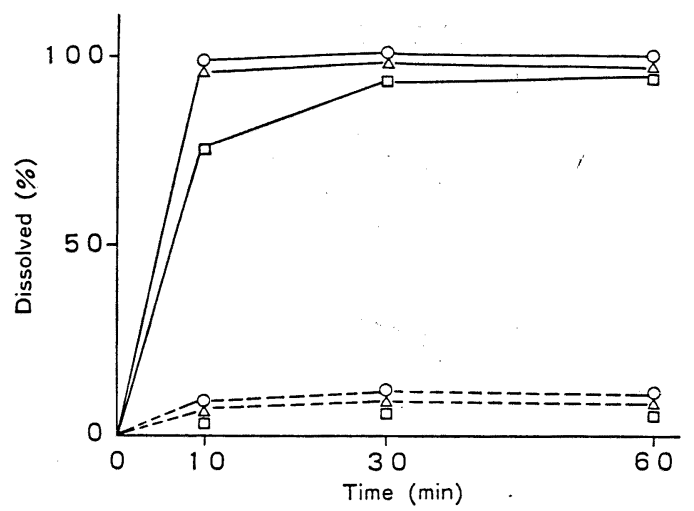

Fig. 1. Effect of Storage on Dissolution Profiles of Nifedipine from SP-RG in Nonpackage Stored at Various R. H. and Temperature under Dark Condition

Storage conditions : $(O)$ initial, $(\triangle)$ $75 \%$ R.H., $20^{\circ} \mathrm{C}$, 30days, ( $\square$ ) $93 \%$ R. H., $30^{\circ} \mathrm{C}$. , 30days.

(-) JP XI 2nd disintegration test fluid

(-- ) JP XII 1st disintegration test fluid

Each point represents the mean value $(n=3)$

75\%，30分後で約100\%であった.

2. 配合直後におけるニフェジピンの溶出挙動 SP-RG と配合薬との配合直後に拈けるニフェ ジピンの溶出挙動は, SP-RG 製剤からのニフェ ジピンの溶出挙動と比較してほとんど変化はなか った。また配合薬による日局第 1 液，第 2 液の $\mathrm{pH}$ の変動はなかった.

3. ポリエチレンセロファンラミネート紙包装 下での配合薬からのニフェジピンの溶出挙動

SP-RG を含む配合薬をポリェチレンセロファ ンラミネート紙で包装し， $20^{\circ} \mathrm{C}, \mathrm{RH} 75 \%$ ならび に $30^{\circ} \mathrm{C}, \mathrm{RH} 92 \%$ での30日後に拉ける溶出挙動 をFig. 2 に示した.

これらの条件下でのニフェジピンの溶出挙動 は, 開封直後の SP-RG 製剤ならびに SP-RG を含む配合薬に比べて，日局第 2 液での 10 分後に おける溶出率が有意に低下した。また日局第 1 液 では炭酸水素ナトリウム配合薬からのニフェジピ 
a) $75 \% \mathrm{RH}, 20 \%$, 30 days

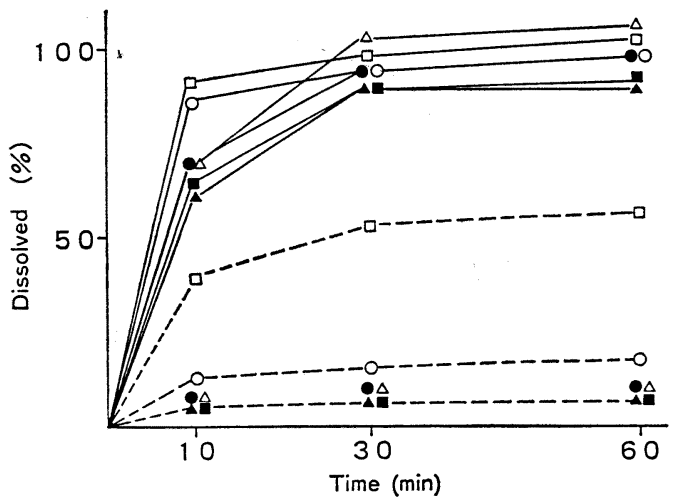

b) $92 \% \mathrm{RH}, 30 \% \mathrm{C}, 30$ days

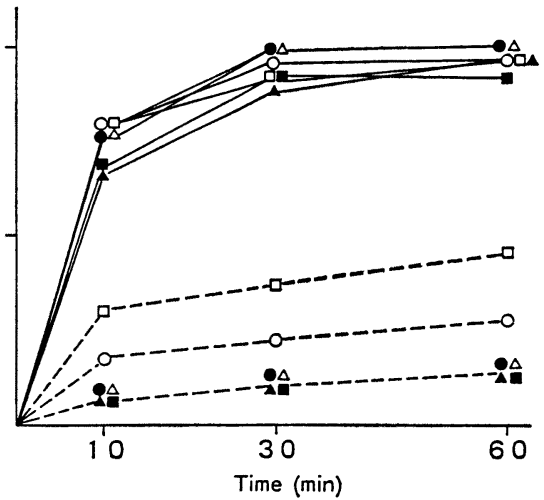

Fig. 2. Dissolution Profiles of Nifedipine from Admixture in Packaged Form under Dark Condition

$(O)$ heavy magnesium oxide, ( $(\bullet)$ LAC B, $(\Delta)$ hustagine, $(\Delta)$ calcium lactate,

( $\square$ ) sodium bicarbonate, ( $\square$ ) MIYA BM

$(\longrightarrow)$ JP XII 2nd disintegration test fluid

(-- ) JP XII 1st disintegration test fluid

Each point represents the mean value $(n=3)$.

ンの溶出率は, 試験開始60分後で約50\%を示し， 無包装の $30^{\circ} \mathrm{C}, \mathrm{RH} 92 \%$ での SP-RG 製剤の結 果に比べて有意に増加した. 同様に酸化マグネシ ウム配合薬からの溶出率も有意増加した.

4. 無包装状態での配合薬からのニフェジピン の溶出挙動

$20^{\circ} \mathrm{C}, \mathrm{RH} 75 \%$ ならびに $30^{\circ} \mathrm{C}, \mathrm{RH} 92 \%$ で30 日間保存した SP-RG を含む配合薬の無包装品で は, 日局第 1 液に打いて炭酸水素ナトリウム配合 薬ならびに酸化マグネシウム配合薬からのニフェ ジピンの溶出率は, SP-RG を含む配合薬の包装 品と同様の結果を示した．また，日局第 2 液では $30{ }^{\circ} \mathrm{C}, \mathrm{RH} 92 \%$ の保存条件に打いて, 試験開始 10 分後, 30 分後ならびに60分後での ニュシジ゚ンの 溶出率は, SP-RG を含む配合薬の包装品に比べ て有意に低下した $(\mathrm{t}$ 検定, $\mathrm{p}<0.05)$.

\section{SP-RG 製剤を粉砕して微末化した時の二} フェジピンの溶出挙動

SP-RG 製剂を粉砕して微末化した時の日局第 2 液でのニフェジピンの溶出率は, 粉碎前と比較 してまったく変わらなかった．また，日局第 1 液 では試験開始 10 分後, 30 分後, 60 分後の ンの溶出率がそれぞれ約 $3 \%$ 増加した（Fig. 3).

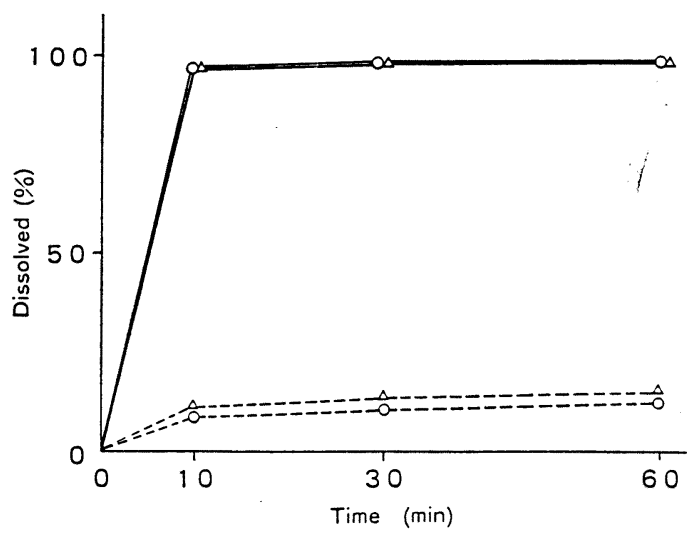

Fig. 3. Effect of Crushing on Dissolution Profiles of Nifedipine from SP-RG $(O)$ SP-RG, $(\Delta)$ Crushing SP-RG

$\longrightarrow$ JP XII 2nd disintegration test fluid

(---) JP XII 1st disintegration test fluid

Each point represents the mean value $(n=3)$

6. 包装の条件によるニフェジピンの光に対す る安定性

SP-RG 製剤をポリエチレンセロファン紙で包 


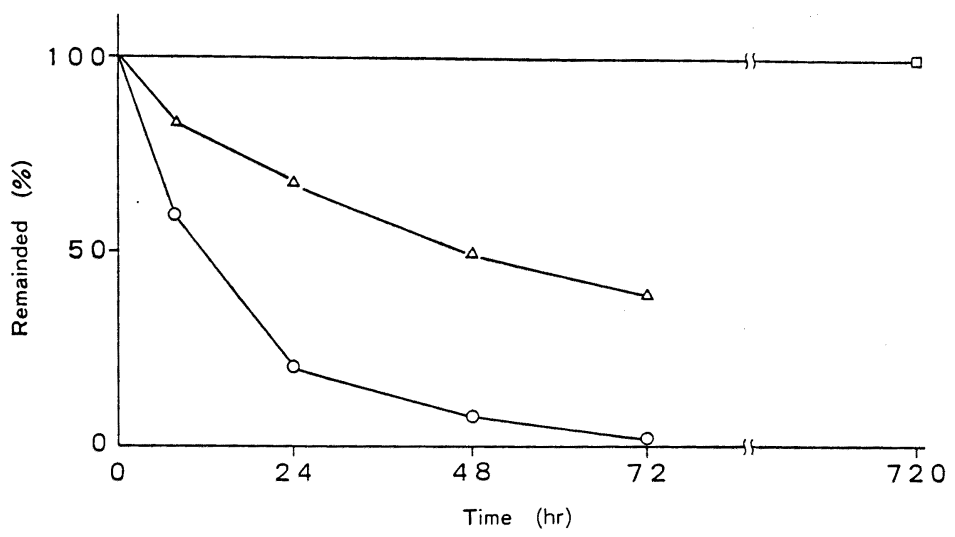

Fig. 4. Effect of Different Packages on Photostability of Nifedipine in SP-RG

(O) polyethylene cellophane laminate packaged form

$(\Delta)$ red glassine packaged form

$(\square)$ aluminium polyethylene laminate packaged form

Each point represents the mean value $(n=3)$

装した場合は72時間の光照射でニフェジピンの残 存率は $2 \%$ 以下で, 非遮光包装下では光照射によ りニフェジピンの安定性が極めて低いことが示さ れた。また赤色グラシン紙でも48時間の光照射で ニフェジピンの残存率は約 $50 \%$ であった。 さらに アルミニウムポリエチレンラミネート紙で再包装 した場合の残存率は約100\%を示した（Fig. 4).

\section{考察}

$\mathrm{SP}-\mathrm{RG}$ 製剤の溶出試験の結果から， SP-RG の溶出挙動は $\mathrm{pH}$ 依存性であることが示された.

すなわち， SP-RG は胃内でニフェジピンの一部 を溶出し，次いで腸内でその残りを速やかに溶出

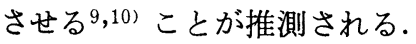

日局第 2 液に怙いて， $20^{\circ} \mathrm{C} ， \mathrm{RH} 75 \% ， 30^{\circ} \mathrm{C}$ RH92\%の条件下で長期（30日）保存した SP-RG 製剂ならびに SP-RG を含む配合薬からのニフェ ジピンの溶出率は, 開封直後の SP-RG に比べて 有意に低下した。このことは，長時間の吸湿によ り SP-RG ならびに SP-RG を含む配合薬がヶ ーキングや固化 ${ }^{4)}$ を起こし分散が悪くなったこと と固体分散体が吸湿によりごく一部のニフェジピ

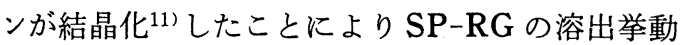
に影響がでたものと思われる。また，吸湿による
ニフェジピンの結晶化についてはX線回析法で検 討したが，SP-RG のニフェジピンの含有量が 2 \%と微量なため確認できなかった。これらのこと より， SP-RG ならびに SP-RG を含む配合薬 は，夏期の高温多湿期には防湿剤を入れた遮光気 密容器に保管する措置を講ずる必要がある.

日局第 1 液に怙いて， $20^{\circ} \mathrm{C} ， \mathrm{RH} 75 \%$ ならび $30^{\circ} \mathrm{C}$ ，RH92\%で30日間保存した SP-RG と炭酸 ナトリウムとの配合薬ならびに SP-RG と酸化マ グネシゥムとの配合薬からのニフェジピンの溶出 率は, 包装・無包装のいずれの状態でも開封直後 の SP-RG に比べて有意に増加した。これは吸湿 により塩基性薬剤（炭酸水素ナトリウム, 酸化マ グネシウム）の表面が局部的に溶解し，アルカリ 性の溶液を形成して，さらにこのアルカリ溶液に より固体分散体の腸溶性部分が溶解することで, ニフェジピンの溶出が促進されたものと推測され る.

一方，ミヤ $\mathrm{BM}$ 㧊よびラック $\mathrm{B}$ は, Table 2 で示すように炭酸水素ナトリウムあるいは酸化マ グネシウムと同様に水溶液中で高い $\mathrm{pH}$ を示して いるが，30ㄷ，RH92\%で30日間保存した無包装 の SP-RG とミャ BM との配合薬ならびに SP$\mathrm{RG}$ とラック $\mathrm{B}$ との配合薬のニフェジピンの溶出 
Table 2. $\mathrm{pH}$ of Compatible Agents in Water $(1 \mathrm{~g} / 20 \mathrm{~m} 1)$

\begin{tabular}{lr}
\hline \multicolumn{1}{c}{ compatible agent } & $\mathrm{pH}$ \\
\hline LAC B & 8.6 \\
hustagine & 6.5 \\
calcium lactate & 7.1 \\
MIYA BM & 8.6 \\
sodium bicarbonate & 8.1 \\
heavy magnesium oxide & 10.7
\end{tabular}

率は開封直後に比べてわずかな増加を示した（ $\mathrm{t}$ 検定, $\mathrm{p}<0.05)$. ミヤ $\mathrm{BM}$ およびラック $\mathrm{B}$ お゙炭 酸水素ナトリウムあるいは酸化マグネシウムと同 様に水溶液中で高い $\mathrm{pH}$ を示す原因は, ミヤ $\mathrm{BM}$ 中に $5 \%$ の沈降炭酸カルシウム, ラック B 中に $8.9 \%$ のメタケイ酸アルミン酸マグネシウムが配 合されていることである。しかし, 沈降炭酸カル シウム拈よびメタケイ酸アルミン酸マグネシウム のニフェジピンとの接触面積は, SP-RG 中の二 フェジピンの含有率が低いことから非常に小さい ことが予想される。それゆ炭酸水素ナトリウム あるいは酸化マグネシウムとの配合品と同様の結 果が得られなかったものと思われる. 以上の結果 から, 炭酸水素ナトリウムならびに酸化マグネシ ウムとの配合は注意が必要である。

粉砕前の SP-RG と粉砕して微末化した SPRG の顕微鏡写真を Fig. 5 に示した. 粉砕して 微末化した SP-RG の粒子径は粉砕前の SP-RG に比べて約 $1 / 4$ 以下に微末化された。 微末化によ る固体分散体への影響を溶出試験により検討した ところ, 日局第 1 液でのニフェジピンの溶出率が 約 $3 \%$ 増加した（Fig. 3).このことにより，腸溶
性固体分散体の一部が物理的に破壊された可能性 が否定できない。しかし，この微末化による影響 は臨床上問題ないと思われる。

$\mathrm{SP}-\mathrm{RG}$ 製剂を赤色グラシン紙で包装した場合 の48時間の光照射後におけるニフェジピンの含量 は約50\%であったが，小川らの報告12)ではニフェ ジピンの原末を用いた赤色グラシン紙での光分解 は光照射48時間後（平均照度 750 lux）において 約 $9 \%$ とされている. しかし, SP-RG の場合は 無晶形のニフェジピンを含む固体分散体であり, 結晶状のニフェジピンの原末に比べ粒子形がきわ めて小さいために, 光に対する安定性が大きく低 下したものと推測される。

本製剂の市販品には，遮光フィルムにて $0.5 \mathrm{~g}$ す゚つ即分包された SP 製品と, $300 \mathrm{~g}$ がプラスチ ック容器に充填された 2 型式がある. 30 分間の光 照射（500lux）によるポリエチレンセロファラミ ネート紙で包装した SP-RG中のニフェジピンの 含量は, $91.7 \%$ と低下したので, $300 \mathrm{~g}$ 包装品か らの調剂は速やかに行わなければならない。また 薬局での保管は完全遮光とし，患者に投薬する際 は遮光ができるアルミニウムポリエチレンラミネ 一ト製の薬袋に保存するよらに指導しなければな らない。また長期にわたる服薬の際に遮光薬袋か らのポリエチレンセロファンラミネート分包品の 出し入れによる曝光も無視できない.今後分包紙 の遮光化などについて，検討を進める予定であ る.

謝辞 ニフェジピンの原末扣よび SP-RG を提供し ていたた゚いた鐘紡株式会社に深謝いたします。

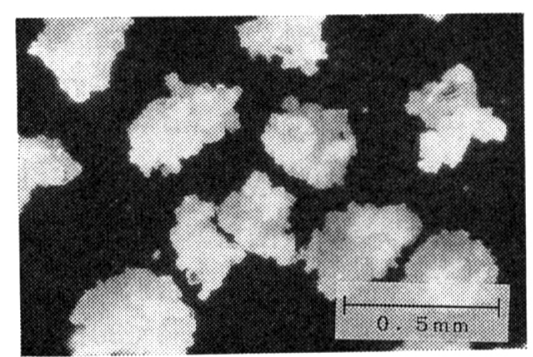

(a)

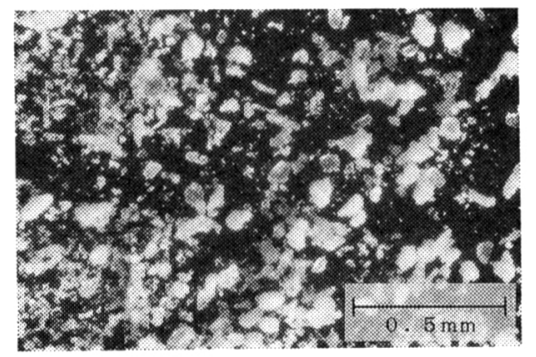

(b)

Fig. 5. Microphotograph $(\times 20)$ of SP-RG (a) and Crushing SP-RG (b) 


\section{引用文献}

1) A. Hasegawa, H. Nakagawa, I. Sugimoto, Chem. Pharm. Bull., 33, 1615-1619 (1985).

2) 長谷川明彦, 田口雅弘, 川村理恵, 中川 寛, 杉 本 功, 薬剤学, 48, 139-145 (1985).

3）長谷川明彦, 川村理恵, 中川 寛, 杉本 功, 薬 学雑誌, 105, 586-592 (1985).

4) 坂爪重明, 山下恒弘, 小野真理子, 佐藤 博, 丹 野慶紀, 相互作用研究会雑誌, 17, 19-24 (1993).

5）杉本 功, 東郷和紀, 佐々木広三, 中川 寛, 松 田芳久, 昌原麗子, 薬学雑誌, 101, 1149-1153 (1981).

6) 井上和秀, 悠山厚司, 木村浩三, 黒田 健, 病院 薬学, 11, 267-275 (1985).
7）久保文苗, 上野高正, 堀岡正義, 幸保文治, 仲井 由宣, 石原 利, 薬凧学, 19, 276-279 (1959).

8) K. Aimoto, K. Kurosaka, H. Nakagawa, I. Sugimoto, Chem. Pharm. Bull., 36, 1483-1490 (1988).

9）杉本 功, 長谷川明彦, 製薬工場, 5, 207-211 (1985).

10）長谷川明彦, 杉本 功, 化学工業, (4), 309-317 (1986).

11）宮崎真理, 伊東孝子, 有森和彦, 岩奥玲子, 中野 真汎, 医学々薬学, 16, 305-318 (1986).

12）小川 聰, 板垣祐一, 早勢伸正, 竹本 功, 笠原 直邦, 阿久津茂隆, 稲垣俊一, 病院薬学, 16 , 189-197 (1990). 